\title{
Geopolymerization: A Review on Physico-chemical Factors Influence to the Reaction Process
}

\author{
Nguyen Hoc Thang* \\ Professor, Faculty of Chemical Technology, Ho Chi Minh City University of Food Industry, Ho Chi \\ Minh City, Viet Nam
}

\begin{abstract}
A geopolymer is one of materials belonging to an inorganic polymer group based on aluminosilicate structural networks. The material is a product of reactions among the activated alumino-silicate resources and solutions of alkaline activators in various conditions. There have been many investigations conducted to produce geopolymer using different raw materials and methods. The chemical factors have a decisive role in the reaction process and the formation of the geopolymeric structural networks. The physical factors significantly influenceon engineering properties, microstructural characteristicsas well as the effectiveness of the reactions. This study is a review on evaluation of relationships among physico-chemical factors in the reaction process. In which, the chemical factors were considered both the alumino-silicate raw materials and alkaline activators. The physical factors were evaluated on the various conditions known as mixing time, curing time and curing temperature.
\end{abstract}

Keywords: Alumino-silicate structural networks, Geopolymerization, inorganic polymer,physico-chemical factors, solutions of alkaline activators

*Author for CorrespondenceE-mail:thangnh@ @ufi.edu.vn

\section{INTRODUCTION}

A geopolymer is the term coined by Joseph Davidovits in the 1970s for the new inorganic polymer materials he developed [1]. Geopolymers consist mainly of amorphous or semi-crystalline phases from the initial geopolymeric reactions and the formation of polymeric $-\mathrm{Si}-\mathrm{O}-\mathrm{Al}-\mathrm{O}-$ bonds $\quad[2,3]$. Davidovits' first studies were carried out between alumino-silicate kaolinite and $\mathrm{NaOH}$ at $100-150^{\circ} \mathrm{C}$ resulting into the formation of atecto-alumino-silicate with structure [1] and bonds as shown in Figure 1.
Studies have been done to understand further the geopolymerization reaction [1-8]. Geopolymerization was then understood as a chain of reactions between different aluminosilicate oxides with silicates in high-alkali environment.

Although Jaarsveld et al. [4] proposed that geopolymerization can proceed from any alumino-silicate sources, more studies have been reported indicating that the geopolymerization only proceeds with amorphous or semicrystalline Al-Si materials [1, 5-8].

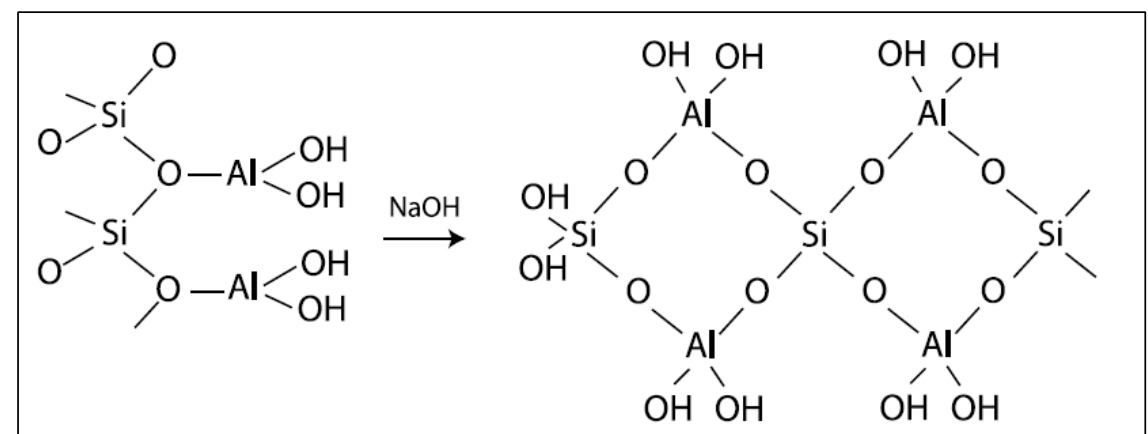

Fig. 1: Structure of First Geopolymeric Generation in Alkali Condition [1]. 
Reactions were described by the formation of every oligomer until the oligomer species combine together into a final geopolymeric product. These detailed reactions were illustrated as follows $[9,10]$, where $\mathrm{M}$ is either sodium $(\mathrm{Na})$ or potassium $(\mathrm{K})$.

$$
\begin{aligned}
& \mathrm{SiO}_{2}+\mathrm{Al}_{2} \mathrm{O}_{3}+2 \mathrm{MOH}+5 \mathrm{H}_{2} \mathrm{O} \\
& \quad \rightarrow \mathrm{Si}(\mathrm{OH})_{4}+2 \mathrm{Al}(\mathrm{OH})_{4}^{-}+2 \mathrm{M}^{+} \\
& \quad \mathrm{Si}(\mathrm{OH})_{4}+\mathrm{Si}(\mathrm{OH})_{4} \\
& \quad \rightarrow(\mathrm{OH})_{3} \mathrm{Si}-\mathrm{O}-\mathrm{Si}(\mathrm{OH})_{3}+\mathrm{H}_{2} \mathrm{O} \\
& \quad \mathrm{Si}(\mathrm{OH})_{4}+2 \mathrm{Al}(\mathrm{OH})_{4}^{-} \\
& \quad \rightarrow(\mathrm{OH})_{3} \mathrm{Si}-\mathrm{O}-\mathrm{Al}^{(-)}(\mathrm{OH})_{3}+\mathrm{H}_{2} \mathrm{O} \\
& \quad \mathrm{Si}(\mathrm{OH})_{4}+2 \mathrm{Al}(\mathrm{OH})_{4}^{-} \rightarrow \mathrm{H}_{2} \mathrm{O}+(\mathrm{OH})_{3} \mathrm{Si}-\mathrm{O}- \\
& \quad \mathrm{Al}{ }^{(-)}(\mathrm{OH})_{2}-\mathrm{O}-\mathrm{Si}(\mathrm{OH})_{3} \\
& \quad(\mathrm{OH})_{3} \mathrm{Si}-\mathrm{O}-\mathrm{Si}(\mathrm{OH})_{3}+(\mathrm{OH})_{3} \mathrm{Si}-\mathrm{O}-\mathrm{Al}^{(--} \\
& \quad(\mathrm{OH})_{3} \rightarrow(\mathrm{OH})_{3} \mathrm{Si}-\mathrm{O}-\mathrm{Al}^{(-)}(\mathrm{OH})_{2}-\mathrm{O}_{-} \\
& (\mathrm{OH})_{2} \mathrm{Si}-\mathrm{O}-\mathrm{Si}(\mathrm{OH})_{3}+\mathrm{H}_{2} \mathrm{O}
\end{aligned}
$$

First, alumino-silicates $\left(\mathrm{SiO}_{2}\right.$ and $\left.\mathrm{Al}_{2} \mathrm{O}_{3}\right)$ are dissolved in alkaline solution and allowed to react, forming tetra-silicate (silicic acid, $\left.\mathrm{Si}(\mathrm{OH})_{4}\right)$ and tetra-aluminate $\left[\mathrm{Al}(\mathrm{OH})_{4}\right]^{-}$ products (reaction (1)). Further reaction of these product forms oligomer precursors such as sialate $(-\mathrm{Si}-\mathrm{O}-\mathrm{Al}-\mathrm{O}-)$ (reaction (3)), sialate-siloxo (-Si-O-Al-O-Si-O-) (reaction (4)) and sialate-disiloxo (-Si-O-Al-O-Si-O$\mathrm{Si}-\mathrm{O}-$ ) (reaction (5)). Combinations of these oligomer precursors form alumino-silicate geopolymer networks [1, 5, 9-11].

Davidovits [12] showed that the products from geopolymerization can be classified into five systems. This classification is based on various $\frac{\mathrm{Si}}{\mathrm{Al}}$ ratios as summarized in Table 1 .

\section{EFFECTS OF RAW MATERIALS TO FORMATION OF POLYMERIC NETWORKS}

Davidovits [1] reported that the required materials for geopolymerization must be high silica and aluminum in amorphous forms, which form polymeric networks under alkaline condition as illustrated in the following Figures 2 and 3.

In the research done by Kumar et al., calcium was determined that it also reacts to form geopolymeric structure similar to mortar and concrete structures in cement hydration process such as $\mathrm{C}-\mathrm{S}-\mathrm{H}, \mathrm{A}-\mathrm{S}-\mathrm{H}, \mathrm{C}-\mathrm{A}-\mathrm{S}-\mathrm{H}$ (with $\mathrm{C}=\mathrm{CaO}, \mathrm{S}=\mathrm{SiO}_{2}, \mathrm{~A}=\mathrm{Al}_{2} \mathrm{O}_{3}$ and $\mathrm{H}=$ $\left.\mathrm{H}_{2} \mathrm{O}\right)[13,14]$. These materials are named in high calcium alkaline activated materials which have the ratio of $\mathrm{Ca} / \mathrm{Si}$ in the range of 0.85 to 1.8 for formation of C-S-H and C-A-S$\mathrm{H}$ gels, and the ratio of $\mathrm{Na} / \mathrm{Si}$ over 0.25 for formation of C-N-S-H and C-N-A-S-H gels [5]. All of these gel structures change the mechanical strength of geopolymer product. Hence, the various ratios between oxides shown in Table 1 will make different structures and affect the technical properties of the products.

Particle size distribution (PSD) of raw materials influences the rate and efficiency of

\begin{tabular}{|c|c|c|}
\hline The mole ratios of $\frac{S i}{\mathrm{Al}}$ & Structures & Applications \\
\hline $\begin{array}{l}20: 1<\text { Si:AlSi:Al } \\
<35: 1\end{array}$ & \multirow[t]{2}{*}{$2 \mathrm{D}$ cross-link } & Fire resistant and heat resistant fiberComposites \\
\hline $3: 1<\mathrm{Si}: \mathrm{Al}$ & & $\begin{array}{c}\text { Sealant for industry } \\
\left(200^{\circ} \mathrm{C}<\text { use }<600^{\circ} \mathrm{C} \text {, tools for aeronautics SPF aluminum }\right.\end{array}$ \\
\hline $\mathrm{Si}: \mathrm{Al}=3: 1$ & $\begin{array}{l}\text { Polymeric } \\
\text { character }\end{array}$ & $\begin{array}{l}\text { Fire protection, fiberglass composite, foundry equipment, heat resistant } \\
\text { composites }\left(200^{\circ} \mathrm{C}<\text { use }<1000^{\circ} \mathrm{C}\right)\end{array}$ \\
\hline $\mathrm{Si}: \mathrm{Al}=2: 1$ & \multirow{2}{*}{ 3D network } & Low $\mathrm{CO}_{2}$, cements and concretes, radioactive and toxic waste, encapsulation \\
\hline $\mathrm{Si}: \mathrm{Al}=1: 1$ & & Bricks, ceramics, fire protection \\
\hline
\end{tabular}
geopolymerization. Similar to theories of ordinary chemical reactions, the finer the powder is, the more rapid the rate of reaction is [7]. This is clearly shown through strength values of product samples after finishing the whole reaction process. The finer the powder is, the higher compressive strength values are. In most of the studies in geopolymer, particle sizes of raw materials are set similar to cement

Table 1: Various Ratios between Si and Al, and their Applications [12, 16,17]. 


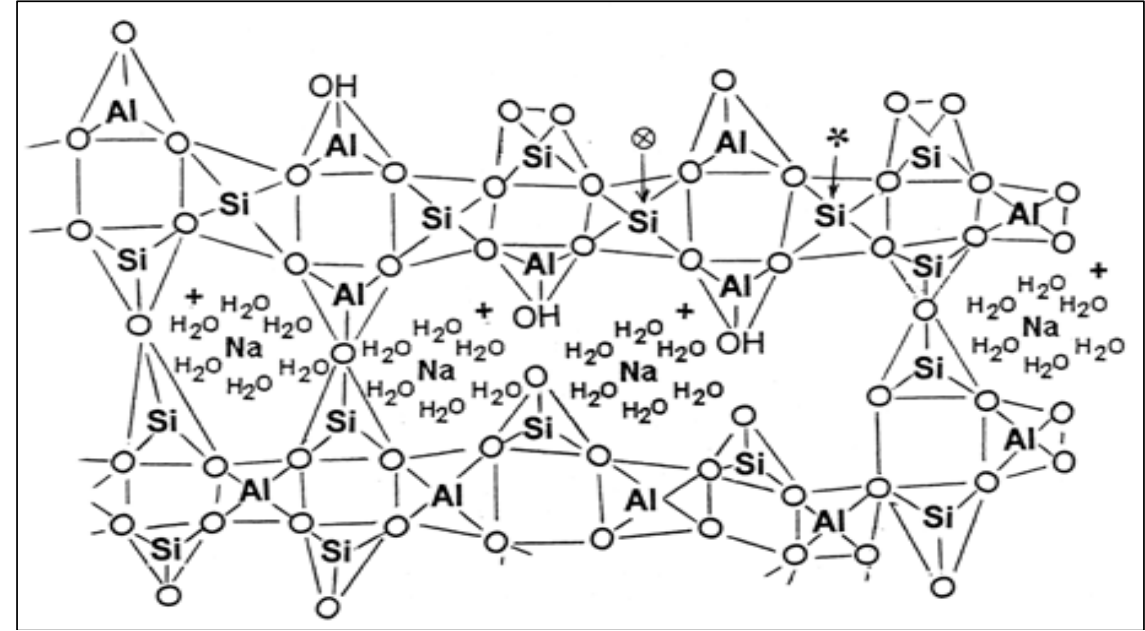

Fig. 2: Structure of Geopolymer in Na-geopolymer System with Semi-schematic [14].

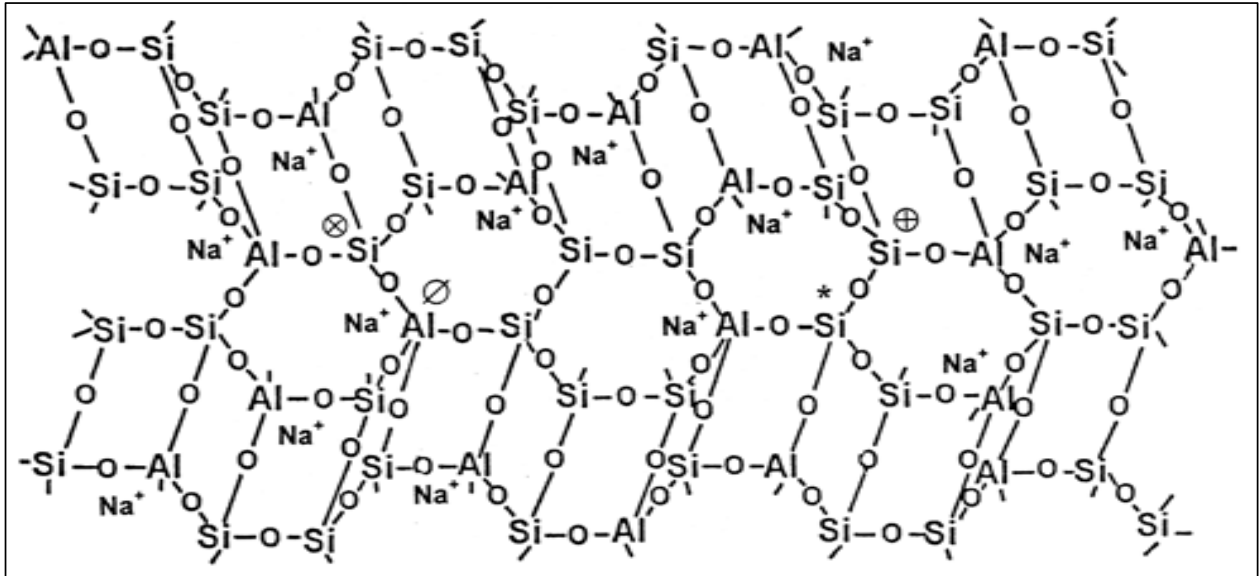

Fig. 3: Structure of Geopolymer in Na-geopolymer System with Three-dimensional Framework [14].

standards to ensure complete hydration reaction [15].For ASTM C115 [15], cement PSD must have $100 \%$ particles under $80 \mu \mathrm{m}$ and over $90 \%$ particles under $50 \mu \mathrm{m}$, with minimum PSD of $7.5 \mu \mathrm{m}$ [15]. In related research, Allahverdi et al. [18] showed the mean pozzolan PSD of $18.5 \mu \mathrm{m}$, while Zhang and $\mathrm{He}$ [7] average PSD was under $38 \mu \mathrm{m}$ for most silicate materials. These values were similar to Kumar et al. [13].

\section{EFFECTS OF ALKALINE ACTIVATORS TO GEOPOLYMERIZATION REACTIONS}

Alkaline activators are compounds formed between anions $\left([\mathrm{OH}]^{-}, \quad\left[\mathrm{SiO}_{3}\right]^{2-}, \quad\left[\mathrm{CO}_{3}\right]^{2-}\right.$, $\left.\left[\mathrm{SO}_{4}\right]^{2-}\right)$ and cations of alkali metals $\left(\mathrm{Li}^{+}, \mathrm{Na}^{+}\right.$, $\mathrm{K}^{+}, \mathrm{Rb}^{+}, \mathrm{Cs}^{+}, \mathrm{Fr}^{+}$), and two commonly used cations are sodium $\left(\mathrm{Na}^{+}\right)$and potassium $\left(\mathrm{K}^{+}\right)$
$[1,5,16]$. Normally, the alkaline activators increase the $\mathrm{pH}$ value when they are dissolved into solutions. And at high $\mathrm{pH}(>12)$, aluminosilicates $\left(\mathrm{SiO}_{2}\right.$ and $\left.\mathrm{Al}_{2} \mathrm{O}_{3}\right)$ are easily dissolved and reacted to form tetra-aluminate $\left(\left[\mathrm{Al}(\mathrm{OH})_{4}\right]^{-}\right)$and tetra-silicate $\left(\mathrm{Si}(\mathrm{OH})_{4}\right.$ or $\mathrm{H}_{4} \mathrm{SiO}_{4}$-acid silicic) $[1,5,11,19,20]$.

Based on the anions, Provis and Deventer [5]classified the alkaline activators into four groups: alkali hydroxides, alkali silicates, alkali carbonates, and alkali sulfates. The alkali hydroxides and alkali silicates are commonly used in geopolymeric research because they are cheaper than others and produced in a large amount all over the world $[1,5]$. For the cations, there has been no study carried out to form the aluminosilicate geopolymeric networks from alkali activators of rubidium $\left(\mathrm{Rb}^{+}\right)$, cesium $\left(\mathrm{Cs}^{+}\right)$, and francium $\left(\mathrm{Fr}^{+}\right)$because these compounds 
are very expensive and scarce. Hence, this study only focused on discussion to the alkali activators of lithium $\left(\mathrm{Li}^{+}\right)$, sodium $\left(\mathrm{Na}^{+}\right)$, and potassium $\left(\mathrm{K}^{+}\right)$.

The alkali hydroxides include $\mathrm{LiOH}, \mathrm{NaOH}$, $\mathrm{KOH}, \mathrm{RbOH}$, and $\mathrm{CsOH}$ (FrOH is not reported because of its scarcity). The $\mathrm{LiOH}$ has the lowest solubility in comparison with the others (at $25^{\circ} \mathrm{C}$, under $5.4 \mathrm{~mol} \mathrm{LiOH} / \mathrm{kg}$ $\mathrm{H}_{2} \mathrm{O}$, over $20 \mathrm{~mol} \mathrm{NaOH}$ or $\mathrm{KOH} / \mathrm{kg} \mathrm{H}_{2} \mathrm{O}$ [21]. The low solubility of $\mathrm{LiOH}$ decreases dissolution of $\mathrm{SiO}_{2}$ and $\mathrm{Al}_{2} \mathrm{O}_{3}$ in solution and cause low effectiveness of geopolymerization reactions $[1,5]$. Moreover, $\mathrm{LiOH}$ as well as $\mathrm{RbOH}$ and $\mathrm{CsOH}$ are of limited large-scale production because of the cost and their scarcity. Both $\mathrm{NaOH}$ and $\mathrm{KOH}$ are produced by electrolysis of chlor-alkali solutions in industrial process which consumed a large amount of electricity. Both the productions of alkali hydroxides and electricity impact strongly and negatively to environment related to greenhouse emissions of $\mathrm{Cl}_{2}$ and $\mathrm{CO}_{2}$ [5]. There are two biggest undesired problems, the high temperature of the solution and efflorescence, when high concentration of alkali hydroxides is dissolved in solution. For high temperature solution, it is reported that 10 mol of $\mathrm{NaOH}$ dissolved in a liter of water can release $90 \%$ of heat (around $400 \mathrm{~kJ}$ ) and increase the temperature of the solution over $90^{\circ} \mathrm{C}[22,23]$. The high temperature of solution in geopolymeric mixtures causes hydrothermal reactions to form zeolite crystals (zeolite crystals are formed over $50^{\circ} \mathrm{C}$ [24] as well as microcracks and macrocracks due to thermal stress gradient. Both phenomena are undesirable to engineering properties of copolymer products, which result in low compressive strength and high water absorption $[1,5,24,25]$. For the efflorescence, this is related to the formation of white carbonate or bicarbonate crystals due to the reaction between the alkali and atmospheric $\mathrm{CO}_{2}$ on the sample surface. This phenomenon can be harmful to the geopolymeric structures in a long time, which is similar to the carbonation in cement-based materials $[1,5]$. Moreover, geopolymers from the alkali hydroxides have lower heat and fire resistance than the geopolymers from the alkali silicates[1,13].
The alkali silicates include sodium and potassium silicates, which have the greatest amount of industrial production as alkaline activators [5]. Lithium silicate with low solubility as well as rubidium and cesium silicates are high costs and the limited industrial production. Therefore, these compounds are not used commonly in research and industry. The sodium and potassium silicates are produced from calcination of carbonate salts and silica and then dissolved in water with the desired ratios. This process also consumes the energy and emitted $\mathrm{CO}_{2}$ but total energy consumption and $\mathrm{CO}_{2}$ emission are much lower than Portland cement production $[5,26-28]$.

Figure 4 showed a portion of the $\mathrm{Na}_{2} \mathrm{O} . \mathrm{SiO}_{2} \cdot \mathrm{xH}_{2} \mathrm{O}$ composition space with crystallization isotherms at $25^{\circ} \mathrm{C}$. It showed a more detailed, complex phase relationship at lower $\mathrm{Si}$ content, which illustrated the potential formation of more siliceous phases observed in hydrothermal geological deposits. In high alkali solution, the silica $\left(\mathrm{SiO}_{2}\right)$ is dissolved and reacted to form silicate oligomer that is monomeric silica, $\mathrm{Si}(\mathrm{OH})_{4}$, which is also known as "orthosilicic or silicic acid" [5]. Therefore, the alkali silicate solutions have lower $\mathrm{pH}$ value (12-13.5) than the alkali hydroxides but an amount of silicate oligomer precursor in alkali silicate solutions will rapidly dissolve and react the solid alumino-silicate resources $\left(\mathrm{Al}_{2} \mathrm{O}_{3}\right.$ and $\left.\mathrm{SiO}_{2}\right)$ in the geopolymer mixtures $[1,5,11,16]$.

Alkali carbonates are compounds of sodium and potassium with carbonate $\left(\left[\mathrm{CO}_{3}\right]^{2-}\right)$ and hydro-carbonate $\left(\left[\mathrm{HCO}_{3}\right]^{-}\right)$that were not commonly used because the alkali carbonate solutions cause low $\mathrm{pH}$ value for geopolymer mixtures, high $\mathrm{CO}_{2}$ emission that directly affects the structure of the geopolymer (high porosity but high water absorption and low compressive strength), and carbonation problems. The other alkali carbonates from lithium, rubidium and cesium are rarely reported due to high cost and scarcity of these compounds. The geopolymer products are also known for having low heat and low fire resistance at high temperature $[1,5,13]$. 


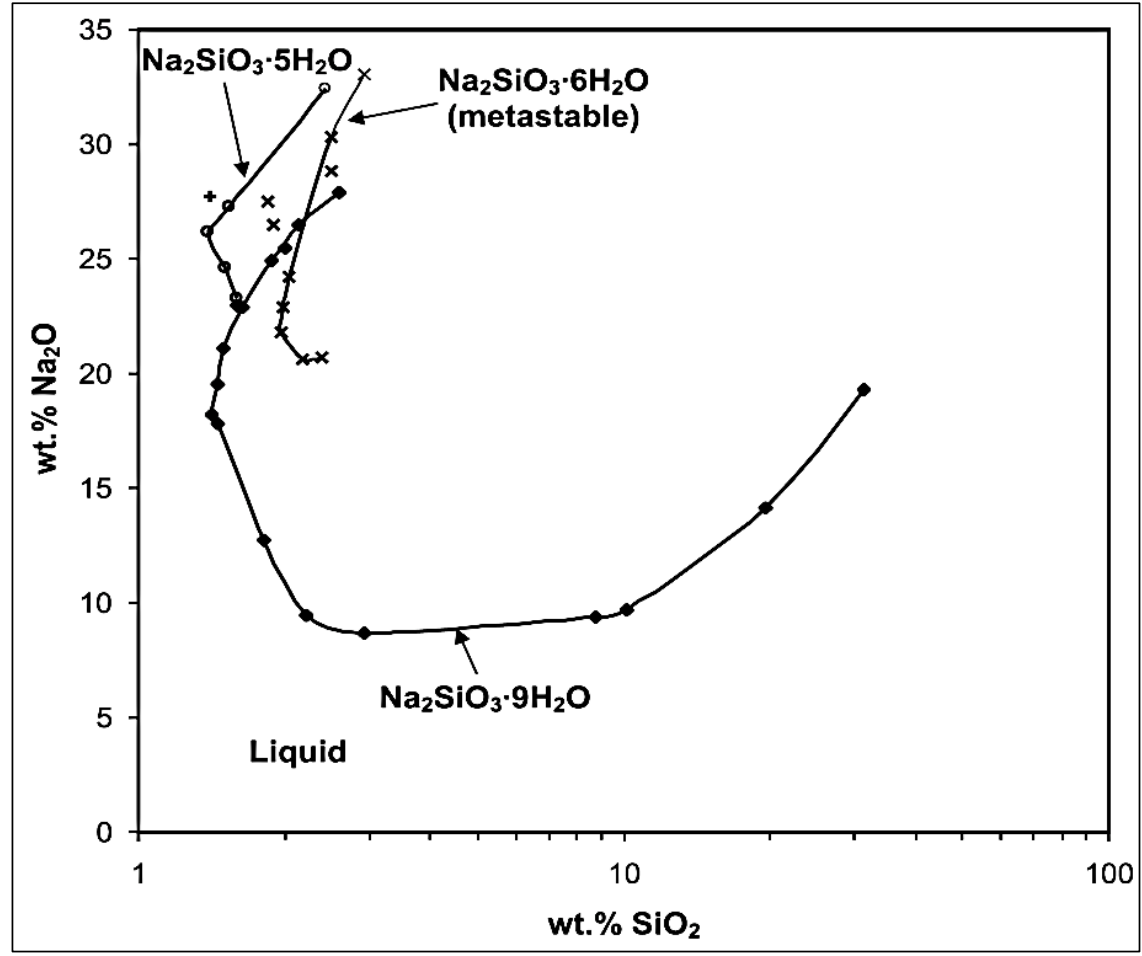

Fig. 4: Crystallisation Isotherms for Hydrated Sodium Metasilicate Phases at $25^{\circ} \mathrm{C}$ [5].

Alkali sulfates are composed of sodium or potassium and sulfate $\left(\left[\mathrm{SO}_{4}\right]^{2-}\right)$ that are used in geopolymerization but limited in research application because the alkali sulfate solutions cannot bring a high $\mathrm{pH}$ value for geopolymer mixtures. There are many complex reactions related to formation and deformation of anhydrous salts (mirabilite$\mathrm{Na}_{2} \mathrm{SO}_{4} \cdot 10 \mathrm{H}_{2} \mathrm{O}$, thernadite- $\mathrm{Na}_{2} \mathrm{SO}_{4}$, metastable heptahydrate- $\mathrm{Na}_{2} \mathrm{SO}_{4} \cdot 7 \mathrm{H}_{2} \mathrm{O}$ ) among alkali $\left(\mathrm{Na}^{+}, \mathrm{K}^{+}\right)$, sulfate $\left(\left[\mathrm{SO}_{4}\right]^{2-}\right)$, and alumino- silicate resources $\left(\mathrm{Al}_{2} \mathrm{O}_{3}\right.$ and $\left.\mathrm{SiO}_{2}\right)$ in the geopolymer mixtures [5].

Among the alkali silicates, the sodium silicate solution or water glass solution has more advantages than potassium silicate solution. The sodium silicate solution is more commonly produced and used than the potassium silicate solution [5]. When the potassium silicate is dissolved in solution, formation of $\mathrm{KOH}$ causes higher standard enthalpy dissolution (around $60 \mathrm{~kJ} / \mathrm{mol}$ ) than dissolution of the sodium silicate (around 45 $\mathrm{kJ} / \mathrm{mol}$ ) [5, 22, 23]. Therefore, the use of high concentration sodium silicate solution could increase the temperature of the geopolymer mixtures, which negatively affects the geopolymerization reactions as well as the hardening process of geopolymer products similarly to increase temperature of solution when used to high concentration of the alkali hydroxides $[1,5]$.

\section{EFFECTS OF THE RATIOS AMONG $\mathrm{H}_{2} \mathrm{O}$ AND $\mathrm{M}_{2} \mathrm{O}, \mathrm{NA}_{2} \mathrm{O}$ AND $\mathrm{SIO}_{2}$}

The foundation of geopolymerization method emphasized the role of $\mathrm{SiO}_{2}$ and $\mathrm{Al}_{2} \mathrm{O}_{3}$ in the formation of alumino-silicate networks. However, Davidovits [1, 12] mentioned that alkali and water are also two necessary factors that directly affect to the geopolymeric reactions. Many investigations focused on these problems to develop and find new solutions for this research field.

Komnitsas and Zaharaki [9] summarized previous investigations and listed in their study about the range of values between oxides ratios used to synthesize geopolymers. The results were used for the production of geopolymeric cements, concretes and ceramics, and they were entirely based on the previous studies as well as the geopolymerization principles of Joseph Davidovits $[5,9,10,12,16]$. The ratios are shown as the Table 2 . 
Table 2: Ratios of Oxides for Geopolymerization [8, 17, 19,29-31].

\begin{tabular}{|l|c|}
\hline \multicolumn{1}{|c|}{ Mole Ratios } & Range of Value \\
\hline $\mathrm{SiO}_{2}: \mathrm{Al}_{2} \mathrm{O}_{3}$ & $3.30-4.50$ \\
\hline $\mathrm{M}_{2} \mathrm{O}: \mathrm{SiO}_{2}$ & $0.20-0.48$ \\
\hline $\mathrm{M}_{2} \mathrm{O}: \mathrm{Al}_{2} \mathrm{O}_{3}$ & $0.80-1.60$ \\
\hline $\mathrm{H}_{2} \mathrm{O}: \mathrm{M}_{2} \mathrm{O}$ & $10-25$ \\
\hline
\end{tabular}

Davidovits as well as Hardjito and Rangan and Provis and Deventer [1, 5, 29] suggested the best mole ratios between oxides to synthesize geopolymer systems like as mortar and concrete are limited in a range of values as follows:

$0.2<\frac{\mathrm{Na}_{2} \mathrm{O}}{\mathrm{SiO}_{2}}<0.28$,

and $15<\frac{\mathrm{H}_{2} \mathrm{O}}{\mathrm{Na}_{2} \mathrm{O}}<17.5$

or $10<\frac{\mathrm{H}_{2} \mathrm{O}}{\mathrm{Na}_{2} \mathrm{O}}<25$

The amount of alkali and water added to the mixture increases the $\mathrm{pH}$ value, and all investigations showed that this value should be over $12[1,5,16]$.

\section{EFFECTS OF MIXING TIME AND CURING REGIMES TO PROPERTIES OF GEOPOLYMER}

This section presents effects of mixing time and curing regimes to properties of geopolymer.

\section{Effects of Mixing Time}

Mixing process affects the distribution of reacted materials in mixture statistically. If the particles of the reactants are distributed evenly and alternately, reactive component diffusion and reaction will occur rapidly and there will be high effect for properties of product in whole geopolymerization process. The longer the mixing time is; the higher strength value of product is [29]. Hardjito and Rangan studied mixing time in two ways: continuous mixing and discontinuous mixing, results of compressive strength of 21-day samples increased from $37 \mathrm{MPa}$ to $51 \mathrm{MPa}$ when mixing time of the mixture was changed from 2 minutes up to 16 minutes, respectively in the case of discontinuous mixing. For continuous mixing, 3-day curing samples, there is an increase of compressive strength for mixing time of 4 and 16 minutes ranging from 40 to $55 \mathrm{MPa}$, respectively [29].

\section{Effects of Curing Time}

According to Davidovits [1], curing require time for reactions proceed completely in geopolymeric mixture. For hydration reaction, curing time is a long time; it can be 1 hour, one day, one month or even all year. For curing time considerations, there are standards in material engineering, ASTM C109/C109M99 [32]. Samples must be tested for mechanical strength after 24 hours, 3, 7, 28 and 90days. Mostly, research for geopolymers apply this standard to check strength of samples.

However, curing time can be shortened by interactions with a reactive environment such as controlling temperature, pressure and humidity. The research of Yunsheng [33] is an example with results shown in Figure 5. Although curing regimes such as at high temperature (around $100^{\circ} \mathrm{C}$ ), in an autoclave, and in steam condition can obtain the results of the higher strength values, these conditions require more energy consumption or the geopolymerization process to take place.

\section{Effects of Curing Temperature}

The temperature of the processes significantly affects geopolymerization reactions. The geopolymer cured in hightemperature condition will obtain better strength in comparison with reference samples. Hardjito and Rangan [29] researched about the effects of curing temperature to compressive strength of 7-day samples. When studied, temperature increased from $25-90^{\circ} \mathrm{C}$ linearly, compressive strength values also raised from 20 to $70 \mathrm{MPa}$ [29]. There have been so many related investigations affirming the role of curing temperature on geopolymeric properties $[1,12,15,31-36]$. 


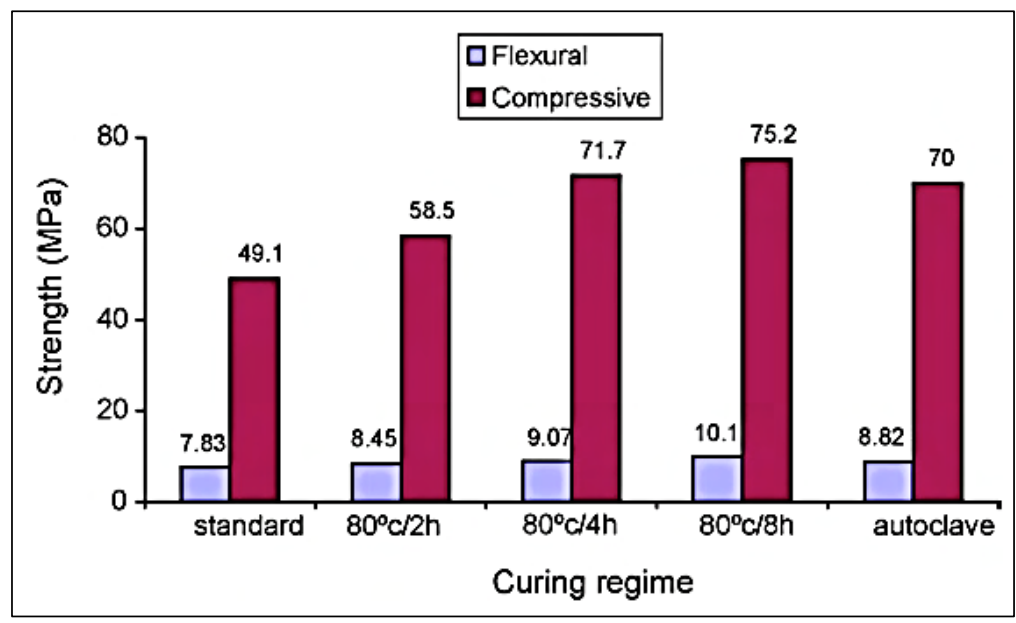

Fig. 5: Effect of different Curing Regime to Strength [33].

\section{CONCLUSION}

The investigations of geopolymer materials have brought many useful solutions for the production process in the future. Because the inorganic polymer materials have a lot of outstanding engineering properties compared to the same traditional products. More specially, the raw materials with high activated alumino-silicate resources can be reused from industrial solid wastes or agricultural residues.

The evaluation of the factors influencing the reaction conditions as well as the product specification will bring various aspects to the geopolymer production efficiency. More importantly, the reaction conditions need to be selected to not only synthesize the high quality geopolymer but also bring about energy saving efficiency as well as simplifying the process of technology.

\section{Nomenclature}

PSD : Particle Size Distribution

ASTM : American Society for Testing and Materials

$v \quad:$ Velocity

\section{REFERENCES}

1. Davidovits, J.Geopolymer Chemistry and Application (5 $5^{\text {th }} \quad$ edition). Institut Géopolymère - France, 2020.

2. Xu H, Deventer JSJV. Effect of Source Materials on Geopolymerization,Ind Eng Chem Res.2003; 42:1698-1706p.

3. $\mathrm{Xu} \quad \mathrm{H}, \quad$ Deventer JSJV.TheGeopolymerisation of Alumino- silicate Minerals. IntJMin Procees. 2000; 59: 247-266p.

4. Jaarsveld JGSV, Deventer JSJV. TheEffect of Metal Contaminants on the Formation and Properties of Waste-based Geopolymers. CemConcr Res.1999;29: 1189-1200p.

5. Provis JL,Van Deventer JSJ.Alkali Activated Materials: State of the art report. RILEM-TC244 AAM. Springer Dordrecht Heidelberg New York London, 2014.

6. Yip CK, Lukey GC, Provis JL, Van Deventer JSJ. Effect of Calcium Silicate Sources on Geopolymerisation. CemConcr Res.2008;38: 554-564p.

7. Zhang G, He J. Geopolymerization of Red Mud and Rice Husk Ash and Potentials of the Resulting Geopolymeric Products for Civil Infrastructure Applications. Developments in Strategic Materials and Computational Design II, The American Ceramic Society, 2011, 45-52p.

8. Nguyen HT, Synthesis and Characteristics of Inorganic Polymer Materials Geopolymerized from Ash of Brickyard, Mater SciForum. 2019; 961: 45-50p.

9. Komnitsas K,Zaharaki D. Geopolymerisation: A Review and Prospects for the Minerals Industry. Min Eng.2007;20: 1261-1277p.

10. Giannopoulou I,Panias D.Structure, Design and Applications of Geopolymeric Materials. $3^{\text {rd }}$ International ConferenceDeformation Processing and Structure of Materials,Belgrade, Serbia, September 20, 22nd, 2007. 
11. Nguyen HT. Evaluation on Formation of Aluminosilicate Network in TernaryBlended Geopolymer Using Infrared Spectroscopy,Solid State Phenomen. 2019, 296, 99-104.

12. Davidovits J.30 Years of Successes and Failures in Geopolymer Applications. Market Trends and Potential Breakthroughs. Geopolymer 2002 Conference, Melbourne, Australia, October 28-29, 2002,1- 16p.

13. Kumar A, Kumar S. Development of Paving Blocks from Synergistic Use of Red Mud and Flyash using Geopolymerization, Constr Build Mater. 2013; 865-871p.

14. Barbosa VFF, MacKenzie KJD, Thaumaturgo C. Synthesis and Characterisation of Materials based on Inorganic Polymers of Alumina and Silica: Sodium Polysialate Polymers. Int $J$ Inorgan Mater. 2000; 2: 309-317p.

15. Ferraris CF, Hackley VA, Aviles AI, Buchanan CA Jr. Analysis of the ASTM Round-Robin Test on Particle Size Distribution of Portland Cement: Phase I. National Institute of Standards and Technology Internal Report 6883, U.S. Department of Commerce Technology Administration, 2002.

16. Petermann JC, Saeed A, Hammons MI. Aklali-Activated Geopolymers: A Literature Review. Distribution A. Approved for Public Release; Distribution Unlimited. 88ABW-2012-2030, 6 February 2012.

17. Le VQ, Do QM, Hoang MD, Dang TP, Bui TH, Nguyen HT.Evaluation on Roles of Activated Silicon and Aluminum Oxides for Formation of Geopolymer from Red Mud and Silica Fume, Key Eng Mater. 2018; 777: 513-517p.

18. Allahverdi A, Mehrpour K, KaniEN.Taffan Pozzolan-based Geopolymer Cement. IUST Int J Eng Sci.2008;19(3): 1-5p.

19. Le VQ, Do QM, Hoang MD, Pham VTHQ, Bui TH, Nguyen HT.Effect of Alkaline Activators to Engineering Properties of Geopolymer-Based Materials Synthesized from Red Mud, Key Eng Mater. 2018; 777: 508-512p.
20. Do QM, Ngo PM, Nguyen HT. Characteristics of a Fly Ash-Based Geopolymer Cured in Microwave Oven. Key Eng Mater. 2020; 850: 63-69p.

21. ASTM C115-96a, Standard Test Method for Fineness of Portland cement by Turbidimeter. American Society for Testing and Materials. Philadelphia June 2000. Sec.4, Vol. 04.01.

22. Gurvich LV, Bergman GA, Gorokhov LN, Iorish VS, Leonidov VY, Yungman VS. Thermodynamic properties of alkali metal hydroxides. Part 2. Potassium, rubidium, and cesium hydroxides. $J$ Phys Chem Ref. 1997;26(4): 1031-1110p.

23. Simonson JM, Mesmer RE, Rogers PSZ. The Enthalpy of Dilution and Apparent Molar Heat Capacity of $\mathrm{NaOH}$ (aq) to 523 $\mathrm{K}$ and $40 \mathrm{MPa}, J$ Chem Thermodyn.1989;21: 561-584p.

24. Cundy CS,Cox PA. The hydrothermal synthesis of zeolites: Precursors, Intermediates and Reaction Mechanism. Microporous and Mesoporous Mater.2005; 82: 1-78p.

25. Santra AK,Luke K.Zeolite Compositions having Enhanced Compressive Strength. US 7,048,053 B2, 2006.

26. Gartner E. Industrially Interesting Approaches to "low- $\mathrm{CO}_{2}$ " Cements. CemConcr Res.2004;34(9): 1489-1498p.

27. Do QM, Bui TH, Nguyen HT.Effects of Seawater Content in Alkaline Activators to Engineering Properties of Fly AshBased Geopolymer Concrete, Solid State Phenomen. 2019; 296:105-111p.

28. Le VQ, Nguyen HT, Bui TH, Pham VTHQ, Do QM, Hoang MD.Leaching Behavior and Immobilization of Heavy Metals in Geopolymer Synthesized from Red Mud and Flyash,Key Eng Mater. 2018; 777: 518-522p.

29. Hardjito D,Rangan BV. Development Flyash-based Geopolymer Concrete: Progress and Research Needs. 2nd Asian Concrete Federation Conference - Bali, Indonesia,November 20-21, 2006.

30. Khale D,Chaudhary R. Mechanism of Geopolymerization and Factors Influencing its Development: A Review. JMater Sci.2007;42: 729-746p.

31. MacKenzie KJD, Komphanchai S, Vagana R. Formation of Inorganic Polymers 
(geopolymers) from 2:1 Layer Lattice Aluminosilicates. $J$ Eur Ceramic Soc.2008;28:177-181p.

32. ASTM C109/109M,Standard Test Method for Compressive Strength of Hydraulic Cement Mortars (Using 2-in. or [50-mm] Cube Specimens). American Society for Testing and Materials. Philadelphia June 2000. Sec.4, Vol. 04.01.

33. Yunsheng Z, Wei S, Qianli C, Lin C. Synthesis and Heavy Metal Immobilization Behaviors of Slag based Geopolymer. J Hazard Mater.2006;143: 206-213p.

34. Nguyen HT, Le TN, Pham VTHQ, Dang TP, Dao TK, Nguyen VP.Development Of Heat Resistant Geopolymer-Based Materials From Red Mud And Rice Husk Ash, AIP Conference Proceedings, 2018; 1954, 040005.
35. Nguyen HT, Nguyen NH, Pham VTHQ, Nguyen NKT, Tran VTA, Pham TK.Engineering Properties Of Lightweight Geopolymer Synthesized From Coal Bottom Ash And Rice Husk Ash, AIP Conference Proceedings, 2018, 1954, 040009.

36. Monnin C, Dubois M. Thermodynamics of the $\mathrm{LiOH}+\mathrm{H}_{2} \mathrm{O}$ system. J Chem Eng. 2005; 50(4): 1109-1113p.

\section{Cite this Article}

Nguyen Hoc Thang. Geopolymerization: A Review on Physico-chemical Factors Influence to the Reaction Process. Journal of Polymer \& Composites. 2020; 8(3): $1-9 \mathrm{p}$. 